\section{Fungicidal Effectiveness of Electrolyzed Oxidizing Water on Postharvest Brown Rot of Peach}

\author{
Muhammad Imran Al-Haq ${ }^{1}$, Y. Seo, S. Oshita, and Y. Kawagoe \\ The University of Tokyo, Graduate School of Agricultural and Life Sciences, \\ Yayoi 1-1-1, Tokyo 113-8657, Japan
}

Additional index words. chlorination, disease suppression, oxidation-reduction (redox) potential, surface sanitation

\begin{abstract}
The fungicidal effectiveness of electrolyzed oxidizing (EO) water on peach [Prunus persica (L.) Batsch.] fruit was studied. Fruit were inoculated with a spore suspension of $5 \times 10^{5}$ conidia/mL of Monilinia fructicola [(G. Wint.) Honey] applied as a drop on wounded and nonwounded fruits, or by a uniform spray-mist on nonwounded fruits. Fruit were immersed in tap water at $26^{\circ} \mathrm{C}$ for 5 or 10 minutes (control), or treated with EO water varying in oxidation-reduction potential (ORP), pH, and free available chlorine (FAC). Following treatment, fruit were held at $20{ }^{\circ} \mathrm{C}$ and $95 \%$ relative humidity for 10 days to simulate retail conditions. Disease incidence was determined as the percentage of fruits showing symptoms of the disease, while severity was expressed as lesion diameter. EO water did not control brown rot in wound-inoculated fruits, but reduced disease incidence and severity in nonwound-inoculated peach. Symptoms of brown rot were further delayed in fruit inoculated by a uniform-spray mist compared with the nonwounded-drop-inoculated peaches. Fruit treated with $\mathrm{EO}$ water held for 8 days at $2{ }^{\circ} \mathrm{C}, 50 \% \mathrm{RH}$, did not develop brown rot, until they were transferred to $20{ }^{\circ} \mathrm{C}, 95 \% \mathrm{RH}$. The lowest disease incidence and severity occurred in fruit immersed in EO water for up to 5 minutes. EO water having pH 4.0, ORP 1,100 mV, FAC $290 \mathrm{mg} \cdot \mathrm{L}^{-1}$ delayed the onset of brown rot to 7 days, i.e., about the period peach stays in the market from a packing house to consumer. No chlorine-induced phytotoxicity was observed on the treated fruit. This study revealed that EO water is an effective surface sanitizer, but only delayed disease development.
\end{abstract}

Brown rot caused by Monilinia fructicola [(G. Wint.) Honey] is one of the most destructive diseases of stone fruits (Prunus sp.) (De Vries-Paterson et al., 1991). The disease appears as blossom blight and progresses into a twig blight and canker, which can provide inoculum for latent infection of the green fruit. From the latent infection, fruit brown rot develops either at the pre- or postharvest stage (Bosch et al., 1992).

The stone fruit industry has had no registered fungicides for control of postharvest brown rot since 1996 (Hong et al., 1998). Hydrocooling of peaches removes field heat from fruit up to 15 times more rapidly than the forced-air method (Boyette et al., 1992), and cleans products by removing chemical residues and debris (Nunes et al., 1995). However, hydrocooling with plain water does not reduce brown rot caused by $M$. fructicola, and tends to disseminate the pathogen (McClure, 1958). To reduce peach decay, the hydrocooling water is chlorinated with sodium or calcium hy-

Received for publication 21 Jan. 2001. Accepted for publication 22 June 2001. We are indebted to Dr. Hideo Ishii, Laboratory of Fungicide Chemistry, National Institute of Agro-Environmental Sciences, Tsukuba, Japan, for providing with the culture of Monilinia fructicola and technical guidance.

${ }^{1}$ To whom reprint requests should be addressed. Tel. +81-3-5841-5373; Fax. +81-3-5841-8174; E-mail: imranintokyo@yahoo.com pochlorite, chlorine or some source of hypochlorite ion (Hicks and Segall, 1974).

Free-chlorine, or available chlorine concentration (ACC), or free available chlorine (FAC), are commonly used terms for unreactive hypochlorous acid ( $\mathrm{HOCl}$ ) and hypochlorite ions. In laboratory tests, $0.2-5 \mathrm{mg} \cdot \mathrm{L}^{-1}$ freechlorine can inactivate cells of various gramnegative bacteria within seconds (Dychdala, 1991), but its effectiveness varies with the microorganisms. Spores of Alternaria alternata [(Fr.:Fr.) Keissl.] are 10-fold less sensitive to free chlorine than cells of Escherichia coli (Segall, 1968). The reaction products of free chlorine may or may not be effective as antimicrobial agents. On contact, $\mathrm{HOCl}$ inactivates microbes immediately (Dychdala, 1991). Since $\mathrm{HOCl}$ is a strong antioxidant, it immediately reacts with many inorganic and organic (debris, wounds on plants, etc.) substances, which reduce its effectiveness against microbes partially or fully embedded in the fruit (Dychdala, 1991; Eckert and Sommer, 1967). However, it is a good surface sanitizer. Chlorine is relatively ineffective when used on inoculated or infected fruit (Eckert and Sommer, 1967), and at low temperature, its effectiveness is further reduced (Segall, 1968). Chlorine levels of 20-300 times greater than those used in the laboratory tests are recommended for dump tanks and flumes to maintain concentrations that can quickly inactivate introduced inocula (Hicks and Segall, 1974).
In addition, such levels of free-chlorine reduce the population of pathogens in shallow wounds on fruit surfaces and delay the onset of disease (Bartz and Crill, 1973). The use of postharvest chlorine dips also has shown potential for reduction of residues of preharvest pesticide on apple fruits (Hendrix, 1991).

Electrolyzed oxidizing (EO) water is the product of a new concept developed in Japan. Research has revealed that addition of deionized water containing $0.2 \%$ sodium chloride to an electrolysis chamber, where the anode and cathode electrodes are separated by a diaphragm, and subjecting the water to electrolysis, imparted strong bactericidal and virucidal properties to the water collected from the anode (EO water) (Venkitanarayanan et al., 1999a). In the process, EO water and electrolyzed reduced (ER) water are produced simultaneously. Chlorine is generated in the anode (acidic or oxidized) water, and $\mathrm{H}_{2}$ in the cathode (alkaline or reduced) water. The $\mathrm{Cl}_{2}$ reacts with the water to form $\mathrm{HOCl}$ and $\mathrm{HCl}$. At low $\mathrm{pH}$ of $\mathrm{EO}$ water, $\mathrm{HOCl}$, which is a very weak acid but a very effective sanitizer, undergoes virtually no hydrolysis to the much less effective hypochlorite ion $\left(\mathrm{OCl}^{-}\right)$(White, 1992). Molecular $\mathrm{Cl}_{2}$, is in equilibrium with the $\mathrm{HOCl}$, and $\mathrm{HOCl}$ and $\mathrm{FAC}$ are probably the major contributors to the sanitizing effect of $\mathrm{EO}$ water (White, 1992). A cascade of redox reaction occurs during electrolysis producing many reactive and toxic compounds, such as ozone, and very highly reactive and short-lived radicals such as $\mathrm{O}^{-}, \mathrm{Cl}^{-}$, and $\mathrm{OH}^{-}$in the $\mathrm{EO}$ water. These compounds contribute to the sanitizing effect of EO water (Shiba and Shiba, 1995).

EO water is being widely used for disinfection purposes in the Japanese hospitals and dental clinics, while EO water effect on food (Izumi, 1999; Venkitanarayanan et al., 1999a, 1999b) and in agriculture industries (Bonde et al., 1999; Grech and Rijkenberg, 1992; Yamaki, 1998) have been studied. Information is lacking on its effect on the fungi on harvested fruit, therefore, the objective of this study was to assess the impact of EO water on the control of brown rot of peach fruit artificially inoculated by different methods with conidial suspension of M. fructicola at postharvest stage.

\section{Materials and Methods}

Fruit material. In 1999 and 2000, mature peaches of $75 \pm 5 \mathrm{~mm}$ diameter were obtained from the Yamanashi Prefecture (Japan) and kept in a cold room at $1{ }^{\circ} \mathrm{C}$ for up to 2 weeks. Cultivar Kawanakajima Hakuhou was treated in 1999 and 'Misaka Hakuhou' and 'Asama Hakutou' were treated in 2000. Fruit were placed on plastic holders (one layer) in commercial cardboard boxes with their stem-end facing up and were preconditioned for 3 to $6 \mathrm{~h}$ prior to inoculation with $M$. fructicola in a chamber at $20{ }^{\circ} \mathrm{C}$ and $95 \%$ relative humidity (RH).

Inoculum. A pure culture of $M$. fructicola was obtained from the Laboratory of Fungicide Chemistry, National Institute of AgroEnvironmental Sciences, Tsukuba, Japan, and cultured in petri dishes on potato dextrose agar 
(PDA; Difco Laboratories, Detroit) for $9 \mathrm{~d}$ at $20^{\circ} \mathrm{C}$. Inoculum was prepared by flooding the surface of the culture with sterile distilled water, loosening conidia with a soft brush, and filtering the suspension through several layers of cheesecloth. The suspension was centrifuged (model CT4D; Hitachi Co., Tokyo) in centrifuge tubes at $3000 \mathrm{~g}$ for $5 \mathrm{~min}$, the supernatant was discarded, and the pellet was resuspended in sterile distilled water. The concentration of fungal spores was measured with a hemacytometer under a microscope, and the spore suspension adjusted to $5 \times 10^{5} \mathrm{conidia} / \mathrm{mL}$.

Preparation of electrolyzed water. Electrolyzed water was produced by electrolysis in a machine manufactured by Mitsubishi Electric Engineering Co. Ltd., Tokyo (model IKS 1005). The current passing through the electrolyzed water generator and voltage between the electrodes were set at 8-10 Amp. and 9-10 $\mathrm{V}$, respectively. A saturated $\mathrm{NaCl}$ solution and tap water from the laboratory supply line (speed: $500 \mathrm{~mL} / \mathrm{min}$ ) were simultaneously introduced into the equipment. The display indicator was continuously watched to observe until the machine stabilized. The Sterilox cell electrolyzed the water, producing EO water and ER water from their respective outlets and were collected in separate containers. These were prepared just before fruit treatment according to the manufacturer's instructions. The $\mathrm{pH}$ and oxidation/reduction potential (ORP) were recorded by a $\mathrm{pH} / \mathrm{ion}$ meter (model EX-20; HORIBA Ltd., Kyoto, Japan). Concentration of free-chlorine in the EO water was determined by using the DPD-test $(\mathrm{N}, \mathrm{N}$ diethyl-p-phenylene diamine) outlined by Palin (1967).

Effect of EO water-I and II on decay of wound-inoculated (WI) peach fruit. 'Kawanakajima Hakuhou' peaches were harvested in July 1999. Two wounds ( $2 \mathrm{~mm}$ deep and $1 \mathrm{~mm}$ wide) were made near the stem end of each fruit with a sterile dissecting needle. Twenty microliters of the suspension of $M$. fructicola was applied to each wound of a fruit with a micropipette. After inoculation, fruits were held at $20^{\circ} \mathrm{C}, 95 \% \mathrm{RH}$ for $24 \mathrm{~h}$. Next day, fruit were divided into nine batches at random and treated with two types of EO water for the immersion periods of $1,5,10$, and $30 \mathrm{~min}$. The properties of EO water-I and II were $\mathrm{pH} 3.0 \pm$ 0.1 , ORP $1,165 \pm 20 \mathrm{mV}$, and FAC $220 \pm 5$ $\mathrm{mg} \cdot \mathrm{L}^{-1}$, and $\mathrm{pH} 6.8 \pm 0.1$, ORP $940 \pm 20 \mathrm{mV}$, and FAC $180 \pm 10 \mathrm{mg} \cdot \mathrm{L}^{-1}$, respectively. The control fruit were immersed in tap water at 26 ${ }^{\circ} \mathrm{C}$ (ambient condition) for $10 \mathrm{~min}$. Following treatment, all fruits were held at $20{ }^{\circ} \mathrm{C}, 95 \%$ RH for $6 \mathrm{~d}$. Each treatment had three replicates of 10 fruits. The experiment was performed twice.

Effect of EO water-III on decay of woundinoculated (WI) and nonwound-inoculated (NWI) peaches. 'Misaka Hakuhou' peaches, harvested in June 2000, were divided into two batches. For the first batch, two wounds ( $2 \mathrm{~mm}$ deep and $1 \mathrm{~mm}$ wide) were made and inoculated as described above. The second batch of fruit were nonwounded and $20 \mu \mathrm{L}$ of inoculum was applied on the same position as on the wounded fruit. After inoculation, fruit were allowed to air-dry for $2 \mathrm{~h}$, followed by treatment with EO water having properties $\mathrm{pH} 5.8$ \pm 0.1 , ORP $990 \pm 5 \mathrm{mV}$, FAC $270 \pm 20 \mathrm{mg} \cdot \mathrm{L}^{-1}$ (EO water-III) for 2, 5, and $10 \mathrm{~min}$. Control fruits were immersed in tap water at $26^{\circ} \mathrm{C}$ for $10 \mathrm{~min}$. Immediately after treatment, fruits were held at $20{ }^{\circ} \mathrm{C}, 95 \% \mathrm{RH}$ for $10 \mathrm{~d}$. The experiment was done twice with three replicates of 10 fruits per treatment.

Effect of EO water-IV on decay of spraymist-inoculated peaches held at two regimes. 'Asama Hakutou' peaches, harvested in July 2000 , were not wounded but inoculated by a uniform spray-mist of $5 \times 10^{5}$ conidia/mL of M. fructicola spore suspension. After inoculation, fruit were allowed to air-dry at $26{ }^{\circ} \mathrm{C}$. After about $2 \mathrm{~h}$ incubation, fruit were treated with EO water of $\mathrm{pH} 4.0 \pm 0.2$, ORP $1,100 \pm 15$ $\mathrm{mV}$, FAC $290 \pm 15 \mathrm{mg} \cdot \mathrm{L}^{-1}$ (EO water-IV), at $26{ }^{\circ} \mathrm{C}$ for 2 or 5 min (Table 3). Control fruit were immersed in tap water at $26^{\circ} \mathrm{C}$ for $5 \mathrm{~min}$. Following treatment, half of the treated fruit were placed at $20^{\circ} \mathrm{C}, 95 \% \mathrm{RH}$. The other half were held at $2{ }^{\circ} \mathrm{C}, 50 \% \mathrm{RH}$ for $8 \mathrm{~d}$, and then were transferred to $20^{\circ} \mathrm{C}, 95 \% \mathrm{RH}$ for evaluation of ripening and disease development. The experiment was performed twice with three replicates of 10 fruits per treatment.

Data recording and statistical analysis. Fruits were examined daily for brown rot development. Disease incidence was calculated as the percentage of fruits that became infected on a particular day. Disease severity was based on the lesion diameter of inoculated sites that became infected. Lesions not originating from the inoculated sites were considered natural infections. Regression analysis was utilized to evaluate relationship between disease incidence/severity and the storage period. To evaluate the effectiveness of EO water, control data were excluded from the regression analysis. Data were analyzed by using GraphPad Prism Software (San Diego) for regression analysis and MSTAT-C (Michigan State Univ., E. Lansing). The means were compared by least square difference (LSD) test at $P \quad 0.05$. Standard errors of means were calculated.

\section{Results}

Effect of EO water-I and II on decay of wound-inoculated peaches. The relationship between incidence and immersion period is presented as regression of means (Fig. 1). Incidence was best described by quadratic function in both types of EO water. Disease incidence $6 \mathrm{~d}$ after treatment in woundedcontrol fruit was $100 \%$, whereas for EO watertreated fruit, it ranged from $20 \%$ to $80 \%$ for EO water-I and $70 \%$ to $95 \%$ for EO water-II (Fig. 1). Suppression of brown rot was dependent on the immersion period as well as the properties of the EO water. Maximum reduction occurred with a 1-min immersion in EO water-I. A 30-min immersion period was ineffective and therefore excluded from the further experiments.

Disease severity (or lesion diameter) increased during the holding period depending upon properties of EO water and the immersion period. The regression equations for all treatments are shown in Table 1. Brown rot first appeared $1 \mathrm{~d}$ after treatment $(2 \mathrm{~d}$ after inoculation) on control fruit and on those immersed for $30 \mathrm{~min}$ in both types of EO water (data not shown). Symptoms were delayed for $3 \mathrm{~d}$ by a 1 -min immersion. The immersion periods of 5 and $10 \mathrm{~min}$ were equally effective up to $2 \mathrm{~d}$ after treatment, but thereafter brown rot developed. The diameter of brown rot lesions was significantly smaller on fruits treated with EO water-I compared to those treated with EO water-II. About $5 \%$ of fruits were naturally infected and developed brown rot symptoms during incubation. Symptoms resulting from natural infections were easily recognized by their distance from the inoculation points and they usually developed more slowly than those resulting from artificial inoculation. No signs of phytotoxicity were evident.

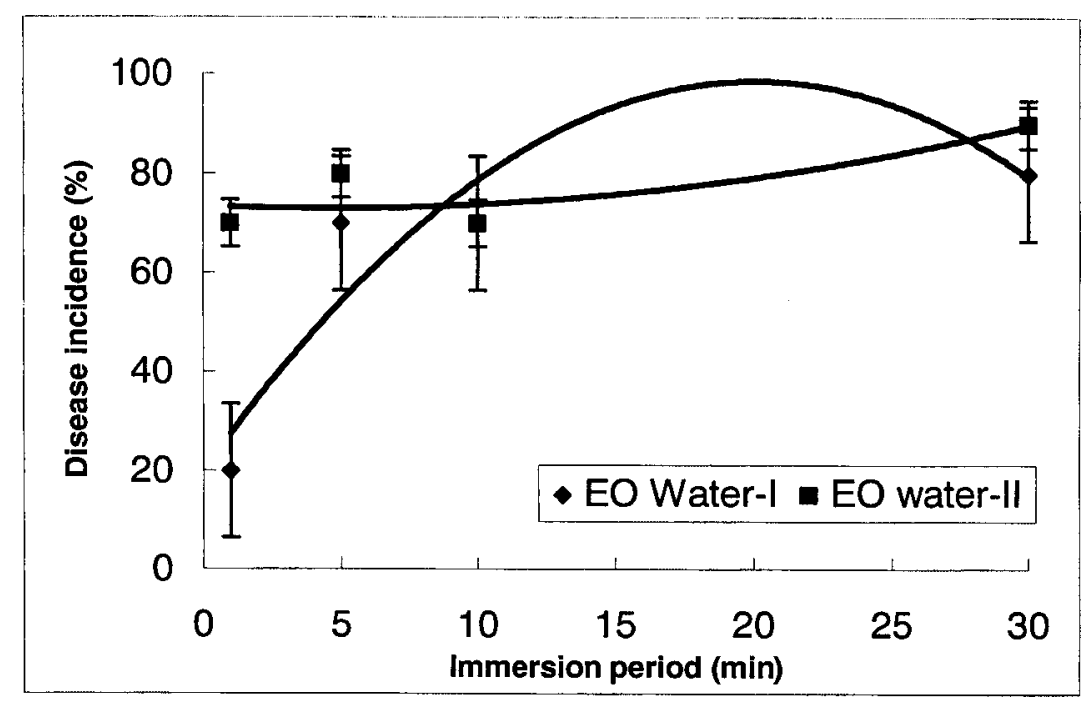

Fig. 1. Regression models for brown rot incidence of 'Kawanakajima Hakuhou' peaches treated with ( EO water-I ( $\mathrm{pH} 3.0$, ORP $1,165 \pm 20 \mathrm{mV}$, and FAC $\left.220 \mathrm{mg} \cdot \mathrm{L}^{-1}\right)\left(\mathrm{Y}=19.918+7.8351 x-0.195 x^{2}, R^{2}\right.$

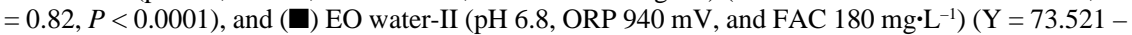
$\left.0.22 x+0.0254 x^{2}, R^{2}=0.73, P<0.04\right)$. Fruit were evaluated after $6 \mathrm{~d}$. Bars indicate standard error. 
Table 1. Linear regression equations for disease severity of 'Kawanakajima Hahukou' peaches after treatment with EO water-I (pH 3.0, ORP $1165 \pm 20 \mathrm{mV}$, and FAC $\left.220 \mathrm{mg} \cdot \mathrm{L}^{-1}\right)$ and EO water-II (pH 6.8, ORP $940 \mathrm{mV}$, and FAC 180 $\left.\mathrm{mg} \cdot \mathrm{L}^{-1}\right)$.

\begin{tabular}{lll}
\hline \hline Treatment & Regression equation & $r^{2}$ \\
\hline EO water-I & & \\
Control & $\mathrm{Y}=11.44 x-10.307$ & 0.95 \\
$1 \mathrm{~min}$ & $\mathrm{Y}=2.8657 x-3.7467$ & 0.96 \\
$5 \mathrm{~min}$ & $\mathrm{Y}=7.86 x-10.993$ & 0.97 \\
$10 \mathrm{~min}$ & $\mathrm{Y}=8.6914 x-11.853$ & 0.98 \\
30 min & $\mathrm{Y}=10.583 x-6.9067$ & 0.99 \\
EO water-II & & \\
Control & $\mathrm{Y}=11.44 x-10.307$ & 0.95 \\
1 min & $\mathrm{Y}=9.7629 x-15.087$ & 0.95 \\
5 min & $\mathrm{Y}=11.446 x-13.66$ & 0.96 \\
10 min & $\mathrm{Y}=9.7229 x-12.013$ & 0.98 \\
30 min & $\mathrm{Y}=9.7629 x-15.087$ & 0.95 \\
\hline $\mathrm{Y}=$ &
\end{tabular}

$\mathrm{Y}=$ lesion diameter $(\mathrm{mm}) ; x=$ holding period (days).

Effect of EO water-III on decay of WI and NWI peaches. The data taken $5 \mathrm{~d}$ after treatment were subjected to regression analysis. Disease development of WI peaches was not affected by treatment with EO water-III but NWI treated were (Fig. 2). Immersion period of 10 min was the most effective in reducing the incidence. Brown rot on 'Misaka Hakuhou' peaches appeared 1 and $2 \mathrm{~d}$ after treatment in WI and NWI controls, respectively (data not shown). After $3 \mathrm{~d}$ of treatment, $100 \%$ of the WI-control fruits had brown rot. Whereas NWIcontrol fruit, $3 \mathrm{~d}$ after treatment, had $40 \%$ and EO treated had $20 \%$ to $30 \%$ incidence. They took $5 \mathrm{~d}$ to develop $100 \%$ incidence (data not shown). Disease development, therefore, was delayed by EO water-III treatment.

Lesion diameter and daily growth rate were also greater in WI fruit compared with NWI fruit. Wounding facilitated fungus penetration into fruit, even in the short incubation period of $2 \mathrm{~h}$, and EO water-III failed to protect WI peaches (Fig. 3). Size of the lesions on NWI fruit was almost half of the size of the WI fruit (Fig. 3). After $10 \mathrm{~d}$ of treatment, the minimum lesion diameter was recorded for the 5-min immersion period for NWI fruits (Fig. 3).

Effect of $E O$ water on decay of spray-mistinoculated peach held at two regimes. Symptoms of brown rot on control fruit of 'Asama Hauktou' peaches appeared after $3 \mathrm{~d}$ of treatment (Table 2) and the onset of symptoms of brown rot was delayed for 9 and $7 \mathrm{~d}$, for 2 - and 5-min immersion periods, respectively (Table 2). A longer immersion period of $5 \mathrm{~min}$ enhanced disease development. After $5 \mathrm{~d}$ of treatment, incidence was $30 \%$ and $0 \%$ in the control and EO water treatments, respectively (Table 2). The minimum lesion diameter was recorded for the 2-min immersion period even after $11 \mathrm{~d}$ of treatment (Table 2). A nonlinear pattern for disease severity was observed for the 'Asama Hakutou' peaches which, after treatment, were held at $20^{\circ} \mathrm{C}, 95 \% \mathrm{RH}$ (Fig. 4). The regression models had correlation coefficients of $0.99,0.97$, and 0.98 for the control, 2- and 5-min treatments, respectively.

The second groups of fruit did not develop brown rot at $2{ }^{\circ} \mathrm{C}, 50 \% \mathrm{RH}$ for $8 \mathrm{~d}$, but gradually started showing brown rot, when they were shifted to $20^{\circ} \mathrm{C}, 95 \% \mathrm{RH}$. Control

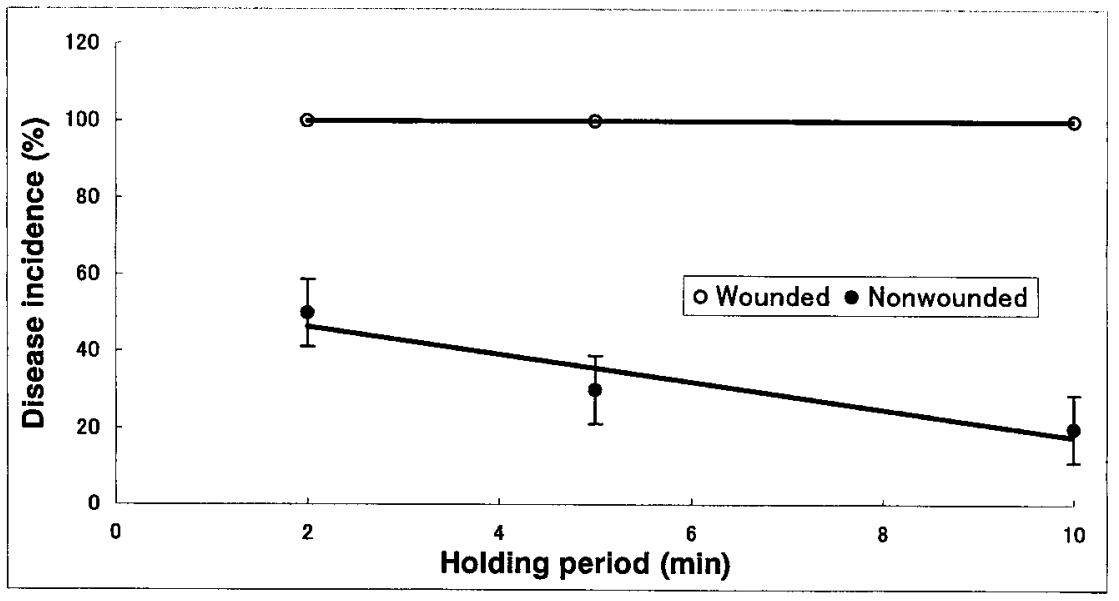

Fig. 2. Regression models for brown rot incidence of 'Misaka Hakuhou' peaches $5 \mathrm{~d}$ after treatment with EO water-III (pH 5.8, ORP $990 \mathrm{mV}$, FAC $270 \mathrm{mg} \cdot \mathrm{L}^{-1}$ at $26^{\circ} \mathrm{C}$ ). Wound-inoculated fruit (O) (no significant function), and nonwound-inoculated fruit $(\bigcirc)\left(\mathrm{Y}=53.571-3.5714 x, R^{2}=0.89, P<0.005\right)$.
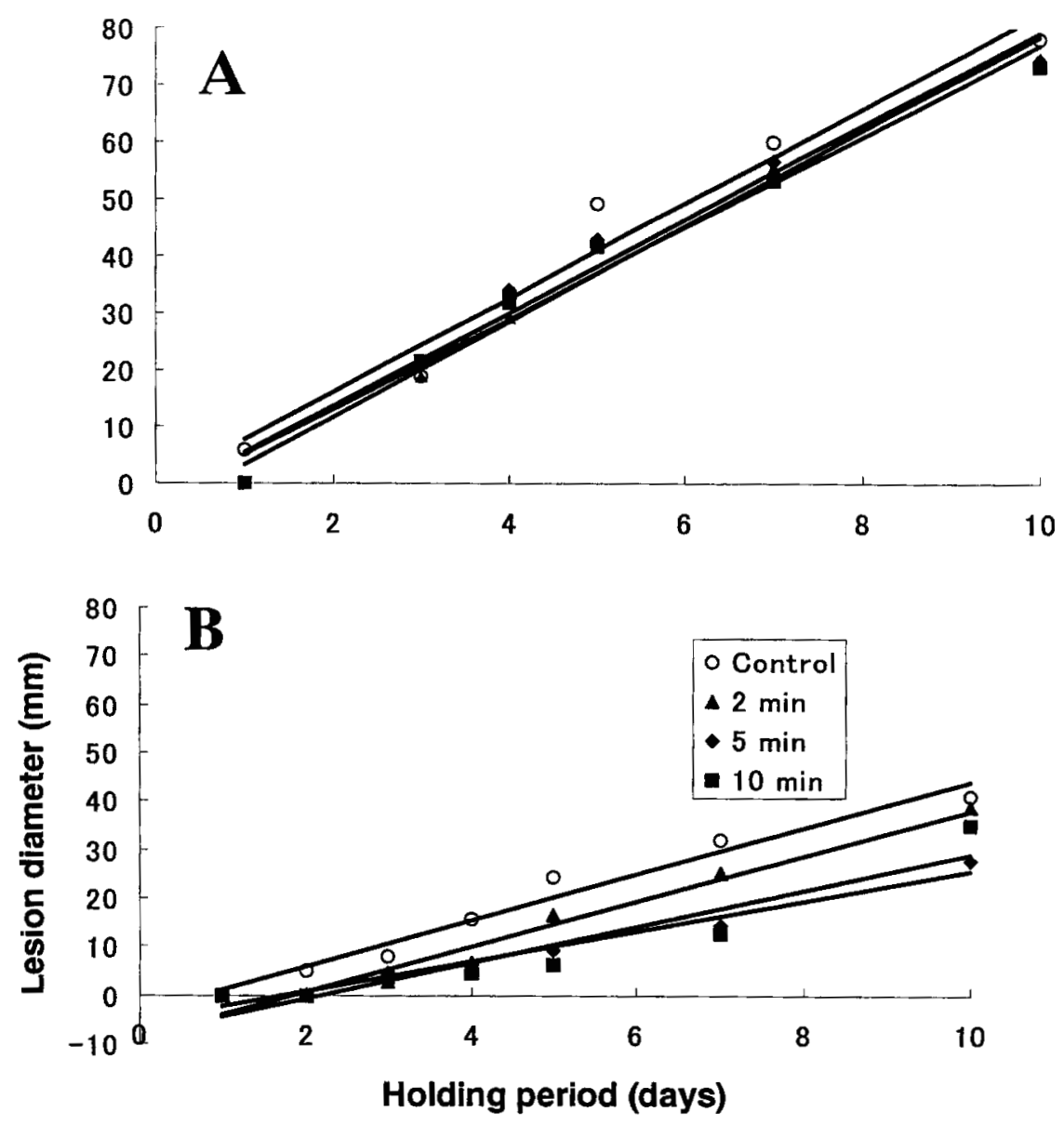

Fig. 3. Regression models for the severity of brown rot of 'Misaka Hakuhou' peaches treated with EO waterIII (pH 5.8, ORP $990 \mathrm{mV}$, and FAC $270 \mathrm{mg} \cdot \mathrm{L}^{-1}$ ) for $(\mathbf{A})$ wound-inoculated (B) nonwound-inoculated fruit, during the $10 \mathrm{~d}$ holding at $20^{\circ} \mathrm{C}, 95 \% \mathrm{RH}$.

fruit showed symptoms of brown rot within 3 d of shifting, while EO water treated fruit (2and 5-min immersion periods) had delayed rot development for 5 and 7 d, respectively (Fig. 5). Disease incidence for a 5-min immersion was $30 \%$ after $7 \mathrm{~d}$ compared with $70 \%$ for the 2-min immersion, and $90 \%$ for the control fruit (Table 2). There were no signs of phytotoxicity on EO water treated peaches. For control fruit a linear pattern was observed for daily brown rot development, whereas for EO water treated fruit nonlinear pattern was recorded (Fig. 5).

\section{Discussion}

EO water reduced but did not prevent brown rot. These results concur with previous findings where some other chemical disinfectants, such as sodium- or calcium-hypochlorite, chlo- 
Table 2. Brown rot incidence of 'Asama Hakutou' peaches treated ${ }^{\mathrm{z}}$ with EO water-IV (pH $4.0 \pm 0.2$, ORP $1100 \pm 15 \mathrm{mV}$, FAC $\left.290 \pm 15 \mathrm{mg} \cdot \mathrm{L}^{-1}\right)$.

\begin{tabular}{|c|c|c|c|c|c|c|}
\hline \multirow[b]{2}{*}{ Group } & \multirow{2}{*}{$\begin{array}{c}\text { Immersion } \\
\text { period }\end{array}$} & \multicolumn{5}{|c|}{ Incidence $(\%)$ on day ${ }^{y}$} \\
\hline & & 3 & 5 & 7 & 9 & 11 \\
\hline \multirow{6}{*}{$I^{\mathrm{w}}$} & Control $^{\mathrm{x}}$ & 26.4 & 32.9 & 45.0 & 67.5 & 67.5 \\
\hline & & (20) a & (30) a & (50) $\mathrm{a}$ & $(85) \mathrm{a}$ & (85) a \\
\hline & $2 \min$ & 0.0 & 0.0 & 0.0 & 36.2 & 45.0 \\
\hline & & $(0) \mathrm{b}$ & (0) b & (0) $\mathrm{c}$ & (35) c & (50) c \\
\hline & $5 \mathrm{~min}$ & 0.0 & 0.0 & 39.2 & 50.8 & 60.5 \\
\hline & & (0) b & (0) b & (40) b & $(60) \mathrm{b}$ & (75) b \\
\hline \multirow[t]{2}{*}{ Days after shifting } & 3 & 5 & 7 & 9 & 11 & \\
\hline & Control $^{\mathrm{x}}$ & 45.0 & 45.0 & 72.1 & 90.0 & 90.0 \\
\hline \multirow[t]{5}{*}{$\mathrm{II}^{\mathrm{v}}$} & & (50) $\mathrm{a}$ & $(50) \mathrm{a}$ & (90) a & (100) a & $(100) \mathrm{a}$ \\
\hline & $2 \min$ & 0.0 & 26.4 & 57.1 & 64.2 & 76.7 \\
\hline & & (0) b & (20) b & (70) b & (70) b & (90) b \\
\hline & $5 \mathrm{~min}$ & 0.0 & 0.0 & 33.1 & 45.0 & 57.1 \\
\hline & & (0) b & (0) c & (30) c & $(50) \mathrm{c}$ & (70) c \\
\hline
\end{tabular}

${ }^{ }$Each fruit was inoculated with a uniform spray-mist of $5 \times 10^{5}$ conidia/mL spore suspension of $M$. fructicola, allowed to air-dry for about $2 \mathrm{~h}$, and treated with EO water-IV at $26^{\circ} \mathrm{C}$.

${ }^{y}$ Means separation by LSD test, $P \quad 0.05$. Data were transformed to arcsin percent before analysis. Figures in parenthesis are nontransformed data.

${ }^{x}$ Control fruit were immersed in tap water for $10 \mathrm{~min}$.

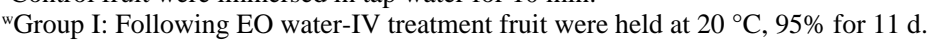

${ }^{v}$ Group II: Following EO water-IV treatment fruit were first held at $2{ }^{\circ} \mathrm{C}, 50 \% \mathrm{RH}$ for $8 \mathrm{~d}$ and thereafter shifted to $20^{\circ} \mathrm{C}, 95 \% \mathrm{RH}$ for another $11 \mathrm{~d}$.

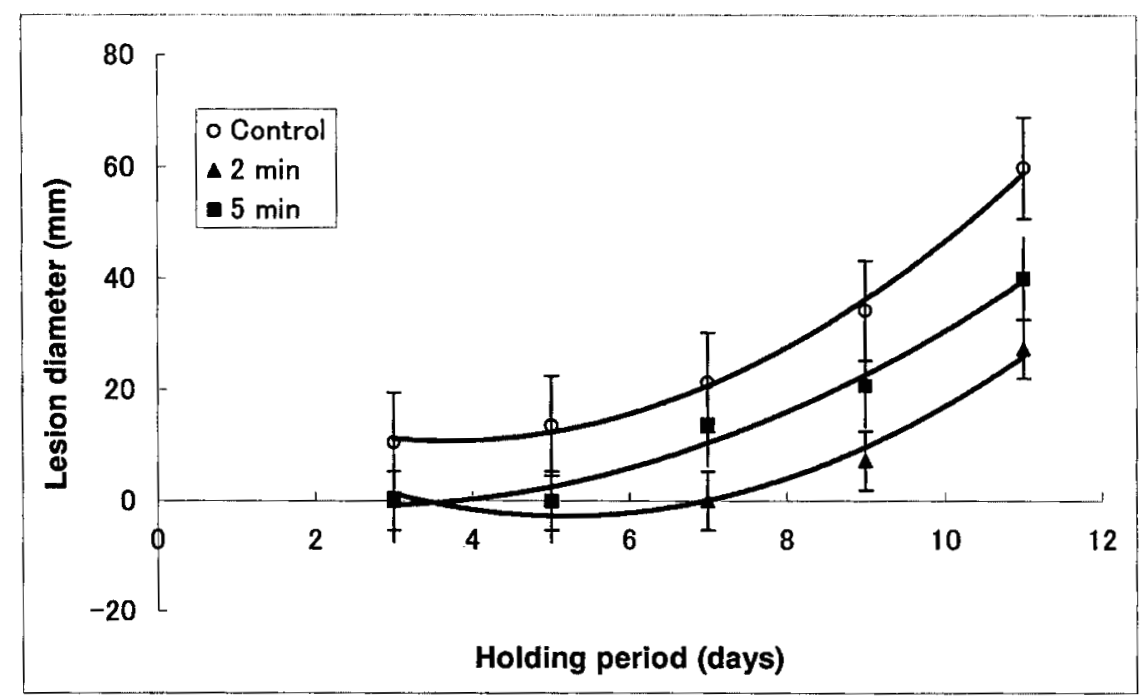

Fig. 4. Regression models for the severity of brown rot of 'Asama Hakutou' peaches after treatment with EO water-IV (pH $4.0 \pm 0.2$, ORP $1100 \pm 15 \mathrm{mV}$, FAC $\left.290 \pm 15 \mathrm{mg} \cdot \mathrm{L}^{-1}\right)$ and held throughout for $11 \mathrm{~d}$ at $20^{\circ} \mathrm{C}, 95 \% \mathrm{RH}$. Control (O) $\left(\mathrm{Y}=22.892-6.6 x+0.8982 x^{2}, R^{2}=0.99\right)$, EO water 2-min immersion (A) $\left(\mathrm{Y}=20.022-8.78 x+0.8452 x^{2}, R^{2}=0.97\right)$, and 5-min immersion $(\mathbf{\square})(\mathrm{Y}=2.8389-2.885 x+$ $\left.0.5661 x^{2}, R^{2}=0.98\right)$. Bars indicate standard error.

rine gas, chlorine dioxide (Bartz, 1988; Ferriera et al., 1996; Hendrix, 1991; Phillips and Grendahl, 1973) were used. The effect of EO water on decay was only significant at $P$ 0.01 . However, disease incidence was relatively high in WI peaches (Table 1), probably because of wounding, inoculation of fruit with the pathogen $24-\mathrm{h}$ prior to treatment, and the application of a relatively high inoculum concentration of $5 \times 10^{5}$ conidia/mL. Brown rot was observed frequently on wounded peach fruits inoculated with $M$. fructicola at a concentration of two spores per wound, i.e., $20 \mu \mathrm{L}$ of $10^{2}$ conidia/mL (Hong et al., 1998). Immersion of $1 \mathrm{~min}$ in EO water-I gave the best reduction in the decay. A reason for greater effect of $1 \mathrm{~min}$ immersion than 5 and $10 \mathrm{~min}$ can be the fact that washing removes fruit waxes as well as ephiphytic bacteria and yeasts (Wilson, 1989).

In the first experiment, the period from incubation to treatment was $24 \mathrm{~h}$, and most of the conidia might have germinated and penetrated into the fruit before treatment. The fruit used in our study resembled fruit inoculated in the orchard prior to harvest. In both inoculations, conidia of $M$. fructicola would have time to germinate and penetrate beneath the fruit epidermis (Smith et al., 1972). For adequate control of fruit decay, pathogens must be inactivated before they become embedded in fruit (Eckert and Sommer, 1967). Decay control of pears was poor when they were inoculated and dried before chlorine treatment (Spotts and Peters, 1980). Although the spore load in our experiments was higher than the minimum required, i.e., $20 \mu \mathrm{L}$ of $10^{2}$ conidia/ $\mathrm{mL}$ (Hong et al., 1998), our results indicated that EO water had some germicidal activity. Decay control with chlorine can be especially poor when used after inoculation (Bertrand and Saulie-Carter, 1979). While chlorine quickly destroys microbes suspended in water, it is less effective on pathogens that are embedded in host tissues, appressed to product surfaces, enclosed in organic matrices such as clamps of decayed tissues, or suspended in water heavily contaminated with microbes that react with chlorine (Dychdala, 1991).

In the later experiment, the incubation period for WI fruit was reduced from $24 \mathrm{~h}$ to $2 \mathrm{~h}$, but the disease development was not affected. Brown rot symptoms were delayed for $2-3 \mathrm{~d}$ in NWI peaches compared with WI fruit, and about a week when a uniform spray-mist of 5 $\times 10^{5}$ conidia $/ \mathrm{mL}$ was used. In general, spray mist inoculation was more effective in reducing decay than drop inoculation (NWI) or wound-inoculation. In general, EO water suppressed brown rot decay on NWI fruit, but was ineffective on WI fruit.

During cold storage at $2{ }^{\circ} \mathrm{C}, 50 \% \mathrm{RH}$ for 8 $\mathrm{d}$, no symptoms of brown rot were evident while those placed at $20^{\circ} \mathrm{C}, 95 \% \mathrm{RH}$, immediately after EO water treatment, were fully decayed during $8 \mathrm{~d}$ storage, and hence indicated that a combination of cold storage with EO water treatment might be better than one treatment (Table 2, Figs. 4 and 5).

Hydrocooling water at $0-4{ }^{\circ} \mathrm{C}$, containing free chlorine, has reduced fungicidal activity (Phillips and Grendahl, 1973). To reduce peach decay, the hydrocooling water usually contains sodium or calcium hypochlorite at a chlorine concentration of $125-200 \mathrm{mg} \cdot \mathrm{L}^{-1}$ (Cardinell and Barr, 1952). However, chlorine is much less effective on spores of pathogens suspended in water at $1^{\circ} \mathrm{C}$ compared with that at $>20{ }^{\circ} \mathrm{C}$ (Dychdala, 1991). However, in the tropical countries with temperatures above 30 ${ }^{\circ} \mathrm{C}$, where hydrocooling is done by dipping in plain water, i.e., without any refrigerating agent (e.g., ice), the use of EO water could be a useful practice. It would not only remove excess field heat but also have a higher germicidal activity.

The $\mathrm{pH}$, as well as immersion period, played a vital role in efficacy of EO water as a disinfectant (Fig. 1, Table 1). Solution $\mathrm{pH}$ is important to the efficacy of chlorinated water as a disinfectant (Dychdala, 1991; Hicks and Segall, 1974). At pH 6, nearly $98 \%$ of the hypochlorite added to water is in the form of $\mathrm{HOCl}$, which is extremely active against microbes; while at $\mathrm{pH} 9.6$, nearly $99 \%$ is in the ion form (Dychdala, 1991). The acid form is up to 80 times more bactericidal than the ion form. In other studies, water chlorination did not reduce postharvest decays of the peach probably due to the high $\mathrm{pH}$ and low temperatures of the solutions, which restrict activity of the chlorine (Bartz, 1988; Dychdala, 1991). Similarly, water chlorination did not prevent decay development in tomato fruit contaminated with Erwinia carotovora subsp. carotovora and then infiltrated with chlorinated water at $26^{\circ} \mathrm{C}$ and pH 6.8 to 9.6 (Bartz, 1988). On the con- 


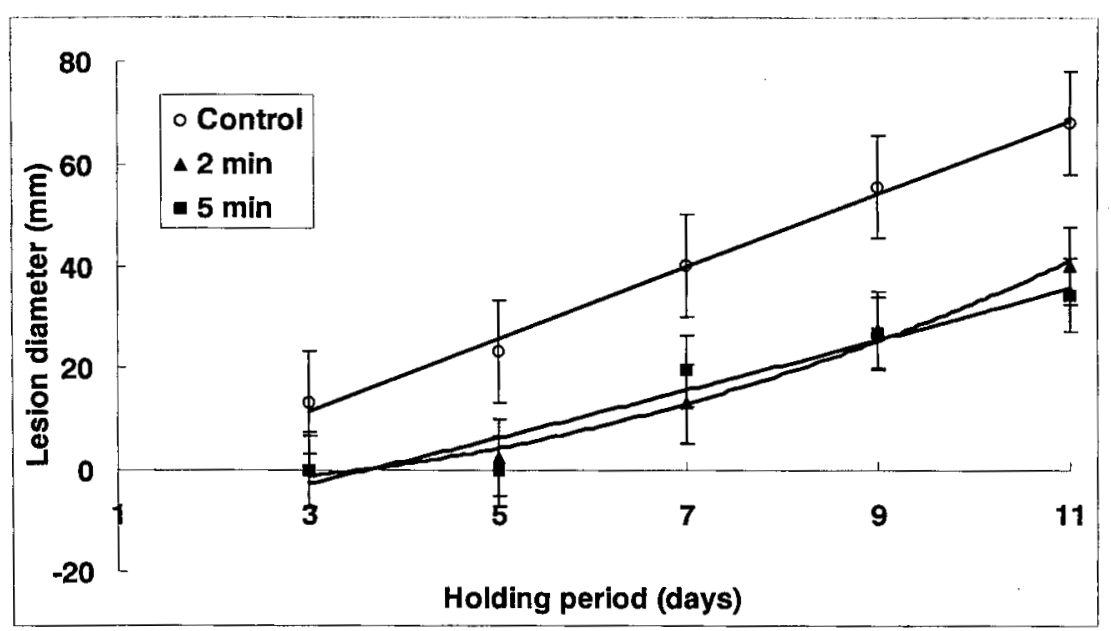

Fig. 5. Regression models for the severity of brown rot of 'Asama Hakutou' peaches treated with EO waterIV (pH $4.0 \pm 0.2$, ORP $1,100 \pm 15 \mathrm{mV}$, FAC $290 \pm 15 \mathrm{mg} \cdot \mathrm{L}^{-1}$ ), and first held at $2{ }^{\circ} \mathrm{C}, 50 \% \mathrm{RH}$ for $8 \mathrm{~d}$ and then shifted to $20^{\circ} \mathrm{C}, 95 \% \mathrm{RH}$ for another $11 \mathrm{~d}$. Control $(\mathrm{O})\left(\mathrm{Y}=-9.61+7.11 x, R^{2}=0.99\right)$, EO water $2 \min (\boldsymbol{\Delta})\left(\mathrm{Y}=-2.6386-0.73 x+0.4286 x^{2}, R^{2}=0.99\right)$, and $5 \min (\boldsymbol{\square})\left(\mathrm{Y}=-15.456+4.15 x+0.0464 x^{2}\right.$, $\left.R^{2}=0.93\right)$. Bars indicate standard error.

trary, in tests with strawberries, a chlorine concentration of $120 \mathrm{mg} \cdot \mathrm{L}^{-1}$ at $\mathrm{pH} 6.5$ protected bruised fruit from inoculum suspended in the hydrocooling water (Ferreira etal., 1996).

The ORP of a solution is an indicator of the ability of the solution to oxidize or reduce, with positive and higher ORP values correlated with greater oxidizing strength (Jay, 1996). Aerobic microorganisms for growth require an optimum ORP of +200 to $+800 \mathrm{mV}$, whereas an optimum range of -200 to -400 $\mathrm{mV}$ is favored for growth of anaerobic microorganisms (Jay, 1996). EO water-I (pH3.0 and ORP $+1165 \mathrm{mV}$ ) proved more effective in suppressing brown rot disease of peach than EO water-II (pH 6.8 and ORP +940 mV). We conclude, therefore, that ORP might have also played a critical role in combination with low $\mathrm{pH}$ and high FAC in suppressing the disease.

According to the manufacturer of the machine, if $\mathrm{pH}$ is set at $\mathrm{pH}<5.0$ then chlorine gas is also produced in addition to the other species of FAC. But if $\mathrm{pH}$ is greater than 5.0 then it is safer to environment as well as operator, because no chlorine gas is produced and FAC comprises of species other than chlorine gas, e.g., $\mathrm{HOCl}$ and $\mathrm{OCl}^{-}$ions. Other advantage of EO water is that it reverts to normal water following use without release of large amounts of harmful gases, such as chlorine. After the initial cost of the electrolysis apparatus, operational expenses are minimal. Thus use of electronically generated chlorine is cost-effective (Grech and Rijkenberg, 1992).

The concentration of FAC in EO water depends upon the concentration of $\mathrm{NaCl}$ solution (in Japan some scientists refer to this solution as original solution) used. Some researchers used $0.2 \% \mathrm{NaCl}$ solution (producing weak EO water) having FAC concentration of 10 to $90 \mathrm{mg} \cdot \mathrm{L}^{-1}$ (Venkitanarayanan et al., $1999 \mathrm{~b})$. We followed the manufacturer's instruction to employ a saturated solution of $\mathrm{NaCl}$ and observed that FAC concentration ranged from 100 to $300 \mathrm{mg} \cdot \mathrm{L}^{-1}$ producing strong EO water.
Peach fruit usually stays in retail shops for a week, about the time that EO water delays disease onset. Therefore, it could be a practicable method in the packinghouse operations, especially for nonwounded fruits.

These studies indicate that sanitation with EO water prevents fruit decay and could become an important alternative to liquid sterilants such as sodium hypochlorite. However, the mechanism by which EO water affects living organisms is not known (Bonde et al., 1999). The extremely high ORP of EO water obviously is a factor in sterilization. ORP rather than $\mathrm{pH}$ was a factor in $\mathrm{EO}$ water stimulation of $T$. indica teliospore germination (Bonde et al., 1999). More research is needed on the EO water properties to determine required properties for decay control.

\section{Literature Cited}

Bartz, J.A. 1988. Potential for postharvest disease in Dis. 72:9-13.

Bartz, J.A. and J.P. Crill. 1973. A study of methods for reducing bacterial soft rot in wounded fresh market tomatoes. Proc. Fla. State Hort. Soc. 68:153-156.

Bertrand, P. and J. Saulie-Carter. 1979. Postharvest decay control of apples and pears after immersion damping. Oregon State Univ. Expt. Sta. Spec. Rpt. 545.

Bonde, M.R., Nester, S.E., A. Khayat, J.L. Smilanick, R.D. Frederick, and N.W. Schaad. 1999. Comparison of effects of acidic electrolyzed water and $\mathrm{NaOCl}$ on Tilletia indica teliospore germination. Plant Dis. 83:627-632.

Bosch, J.R., A.R. Gonzalez, J.K. Mitchell, and J.M. Aselage. 1992. Quality changes in peach puree by brown rot (Monilinia fructicola) and biological control agents. J. Food Qual. 15:449-458.

Boyette, M.D., E.A. Estes, and A.R. Rubin. 1992 Hydrocooling. Maintaining the quality of North Carolina fresh produce. North Carolina Agr. Ext. Serv. Circ. 414-4.

Cardinell, H.A. and C.G. Barr. 1952. Postharvest tests with peaches to reduce spoilage. Michigan State Univ. Agr. Expt. Sta. Quart. Bul. 35:39-51.

De Vries-Paterson, R.M., A.L. Jones, and A.C.Cameron. 1991. Fungistatic effects of carbon dioxide in a package environment on the decay of Michigan sweet cherries by Monilinia fructicola. Plant Dis. 75:943-946. tomato fruit infiltrated with chlorinated water. Plant
Dychdala, G.R. 1991. Chlorine and chlorine compounds, p. 131-151, 167-195 In: S.S. Block (ed.). Disinfection, sterilization, and preservation. $4^{\text {th }}$ ed. Lea and Febiger, Philadelphia.

Eckert, J.W. and N.F. Sommer. 1967. Control of diseases of fruits and vegetables by postharvest treatments. Annu. Rev. Phytopathol. 5:391-432.

Ferreira, M.D, J.A. Bartz, S.A. Sargent, and J.K. Brecht. 1996. An assessment of the decay hazard associated with hydrocooling strawberries. Plant Dis. 80:1117_ 1122.

Grech, N.M. and F.H.J. Rijkenberg. 1992. Injection of electronically generated chlorine into citrus microirrigation systems for the control of certain waterborne root pathogens. Plant Dis. 76:457-461.

Hendrix, F.F. 1991. Removal of sooty blotch and flyspeck from apple fruit with a chlorine dip. Plant Dis. 75:742.

Hicks, J.R. and R.H. Segall. 1974. Water chlorination for vegetable packinghouses. Veg. Crops Fact Sheet VC-1, Fla. Coop. Ext. Serv. Univ. of Florida Inst. Food Agr. Sci., Gainesville.

Hong, C.X., T.J. Michailides, and B.A. Holtz. 1998 Effects of wounding, inoculum density, and biological control agents on postharvest brown rot of stone fruits. Plant Dis. 82:1210-1216.

Izumi, H. 1999. Electrolyzed water as a disinfectant for fresh-cut vegetables. J. Food Sci. 64:536-539.

Jay, J.M. 1996. Modern food microbiology. $5^{\text {th }}$ ed. Aspen Publishers, Frederick, Md. p. 48-49.

McClure, T.T. 1958. Brown and rhizopus rots of peaches as affected by hydrocooling, fungicides, and temperature. Phytopathology 48:322-323.

Nunes, M.C.N., J.K. Brecht, A.M.M.B. Morais, and S.A. Sargent. 1995. Physiological and chemical quality characteristics of strawberries after storage are reduced by a short delay to cooling. Postharvest Biol. Technol. 6:17-28.

Palin, A.T. 1967. Methods for the determination, in water of free and combined available chlorine, chlorine dioxide and chlorite bromine, iodine, and ozone, using diethyl-p-phenylene diamine (DPD). J. Inst. Water Engineers 21:537-543.

Phillips, D.J. and J. Grendahl. 1973. The effect of chlorinating hydrocooling water on Monilinia fructicola conidia and brown rot. Plant Dis. Rpt. 57:814-816.

Segall, R.H. 1968. Fungicidal effectiveness of chlorine as influenced by concentration, temperature, $\mathrm{pH}$, and spore exposure time. Phytopathology 58:14121414.

Shiba, A. and K. Shiba. 1995. Strong Ionized Water Handbook. Dept. of Dentistry, Showa Univ., and Dept. of Dentistry, Tokyo Medical and Dental Univ. Igoku Joho Co., Ltd.

Smith, W.L., Jr., R.W. Penny, and R. Grossman. 1972 Control of postharvest brown rot of sweet cherries and peaches with chemical and heat treatments. USDA Mkt. Res. Rpt. 979.

Spotts, R.A. and B.B. Peters. 1980. Chlorine and chlorine dioxide for control of d'Anjou pear decay. Plant Dis. 64:1095-97.

Venkitanarayanan, K.S., O.I. Ezeike, Y. Hung, and M.P. Doyle. 1999a. Efficacy of electrolyzed oxidizing water for inactivating Escherichia coli O157:H7, Salmonella enteritidis, and Listeria monocytogenes. Appl. Environ. Microbiol. 65:4276-4279.

Venkitanarayanan, K.S., O.I. Ezeike, Y. Hung, and M.P. Doyle. 1999b. Inactivation of Escherichia coli O157:H7 and Listeria monocytogenes on plastic kitchen cutting boards by electrolyzed oxidizing water. J. Food Prot. 62: 857-860.

White, G.C. 1992. Handbook of chlorination and alternative disinfectants. Van Nostrand Reinhold Co. New York.

Wilson, C.L. 1989. Managing the microflora of harvested fruits and vegetables to enhance resistance. Phytopathology 79:1387-1390.

Yamaki, Y.T. 1998. Disease control with functional water. Workshop: Sustainable development in horticulture in Asia and Oceania. 10 Nov. 10 1998. The Univ. Tokyo, Japan. p. 10-15. 